\title{
肝門部胆管閉塞に対する部分的胆道減圧術後の
}

\author{
胆汁中ビリルビン排泄に関する実験的研究
}

\author{
兵庫医科大学第 1 外科 \\ 田中 信孝 岡本 英三 神野 浩樹
}

\section{EXPERIMENTAL STUDY ON BILIARY EXCRETION OF BILIRUBIN AFTER PARTIAL BILE DRAINAGE IN BILE DUCT OBSTRUCTION AT HEPATIC HILUM}

\author{
Nobutaka TANAKA, Eizo OKAMOTO and Hiroki KANNO
}

The First Department of Surgery, Hyogo College of Medicine

肝門部胆管閉塞部分的解除後の胆汁分泌動態・ビリルビン排泄の検討のため, ラットで $30 \%$ 領域胆 管を外瘦とした。主として胆汁酸負荷による検討で，a）70\%選択的胆管閉塞 (SBO) で対照と同等の 胆汁分泌・ビリルビン排泄能を，70\%選択的胆汁血症で胆汁分泌穴進のないビリルビンの排泄増加を 認めた。 b) 黄疸群では閉塞解除早期に大量のビリルビン排泄をみた後, $70 \% \mathrm{SBO}$ と $30 \% \mathrm{SBO}$ の同時 施行 1 週間群が対照と同等の反応を示し, $70 \% \mathrm{SBO} 3$ 週間 $30 \% \mathrm{SBO} 1$ 週間の異時性選択的閉塞群で は胆汁分泌のえ進ビリルビン排泄の著しい低下をみた。 以上は, 肝門部胆管閉塞での減黄効果, 胆汁 分泌動態を念頭においた臨床的対応の必要性を示唆するすのである.

象引用語：肝門部胆管閉塞, 部分的胆道減圧, 胆汁中ビリルビン

\begin{abstract}
緒
閉塞性黄疾に対する経皮経肝胆道ドレナージ（percutaneous transhepatic cholangio drainage, 以下 PTCD と略す)などの減黄処置の有用性は周知のとこ ろであるが，胆管の分断をみる肝門部胆管閉塞では減 黄効果がいかなる機序で得られ，その効果を左右する ものが何かについての一定の見解はいまだない。また， 血清ビリルビン值の低下に最も重要と考えられる胆汁 中へのビリルビン排泄機序 ${ }^{122}$ に関しても不明な点が 多い，昨今，術前 PTCDの是非に関する議論が多 (、3) 5)ことから，その意義を明らかにする意味でも胆 道減圧術後の胆汁ビリルビン排泄機序の解明は急務と いえる. 今回, 臨床的かつ実験的に, 選択的胆管閉塞6) が通常顕性黄嗵を伴わないこと，更に胆管の分断をみ る肝門部胆道完全閉塞例でる日常臨床ではしばしばー 側胆管ドレナージのみが施行され, 部分的胆道減圧で 比較的良好な减黄が得られることに着目し、ラットで
\end{abstract}

$<1988$ 年 10 月 12 日受理 $>$ 別刷請求先：田中 信孝 干289-25 旭市イの 1326 旭中央病院外科
選択的胆管閉塞モデルと部分的胆汁血症モデルとの病 態の美異を明らかにした後, 肝門部胆管閉塞を想定し た種々の胆道閉塞状態での部分的胆道减圧後のビリル ビンの胆汁排泄動態につき検討を加えた。

実験材料および方法

実験 I.

まず, 短期選択的胆管閉塞時の病態と胆汁うっ滞の 有無による胆汁分泌動態の差異を明らかにすべく, 以 下の実験を行った。体重 $250 \mathrm{~g}$ 前後の Wistar 系ラット 30匹を用いた。 エーテル麻醉下に $70 \%$ 領域(左葉 L+中 葉 M) の胆管の選択的遮断 (selective bile duct obstruction, 以下 $70 \% \mathrm{SBO}$ 群) と, 70\%領域胆管を腰 静脈に silicone tube (内径0.012インチ, 外径0.0251 ソチ，Dow Corning）を用いてバイパスさせた $70 \%$ 胆 管下大静脈瘻 (choledocho-caval fistula，以下70\% $\mathrm{CCF}$ ) 群とを作成した（図 1)。単開腹・胆管非遮断 (sham op, 以下 SH) 群も同時に作成し，48時間後に 前 2 者は $30 \%$ 領域のみ（右葉 $\mathrm{R}+$ 尾状葉 $\mathrm{C}+$ 乳頭突起 P)の選択的胆汁ドレナージ (selective bile duct drainage，以下 SBD），後者は全肝胆汁ドレナージ（100\% 
困 1 実験 I のモデル

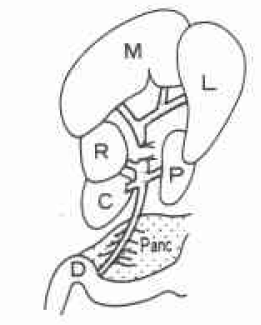

$70 \%$ selective biliary obstruction (70\% SBO)

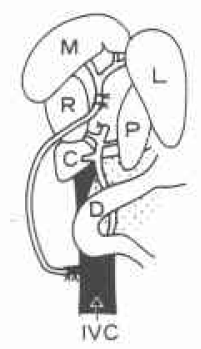

$70 \%$ choledocho-caval fistula

$(70 \% \mathrm{CCF})$
BD)施行した. 胆汁ドレナージに際しては, 膵上縁膵 管が胆管に合流させる直上の胆管に減菌した silicone tube(内径0.012インチ, 外径0.025インチ, Dow Corning）を挿入した。

1. 血液生化学抢よび組織学的検討

胆汁ドレナージ直前の 3 群のラットのらち各 5 匹を まず門脈血 $1 \mathrm{ml}$ 採取後脱血犠死させ, 採肝した。血液は 生化学検查に供し, 摘出肝は $10 \%$ ホルマリンで固定後, Hematoxylin-Eosin 染色施行した。

2. 胆汁外瘦時の胆汁分泌測定

胆汁外癭状態としたラットを Bollman cage に拘束 固定下 15 分間隔で 2 時間遮光下に胆汁採取した. 1 分 間の平均流量 (Mettler-HL 52型分析用電子天科によ り秤量し, 比重を 1 として流量に換算) を求め, 各分 画の総胆汁酸濃度, 総ビリルビン濃度を測定した。総 胆汁酸の測定は $3 \boldsymbol{\alpha}$-hydroxysteroid dehydrogenase 法りによった。総ビリルビンの測定はMalloy \& Evelyn ${ }^{8)}$ の法によった。

\section{3. 統計学的解析}

測定值の有意差検定は Student $\mathrm{t}$ test を用い，危険 率 $5 \%$ 以下を有意差ありとした。

\section{実験 II.}

次に, 慢性胆道閉塞時の病態括よび部分的胆汁外瘦 時の胆汁分泌動態を明らかにすべく，以下の実験を 行った。初期体重 $250 \mathrm{~g}$ 前後の wistar 系雄ラット60匹 を用いた。 エーテル麻醉下，可及的清潔操作により開 腹し，70\%領域 (左葉十中葉) の胆管の選択的遮断 (以 下 SBO) 施行群. $70 \%$ 領域と残り $30 \%$ 領域（右葉十尾 状葉十乳頭突起）胆管の別個の同時的遮断（total bile duct obstruction, 以下 TBO）施行群. 単開腹・胆管

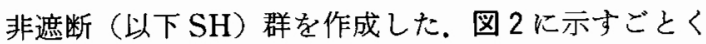

图 2 实驗四のデル

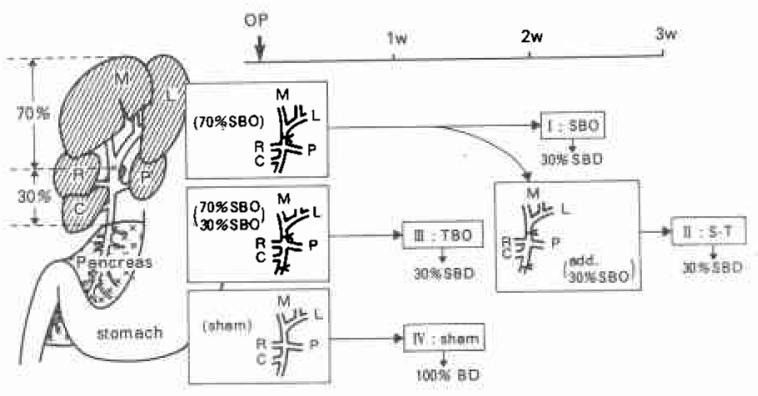

$\mathrm{SBO}$ 群は 2 週間後に非閉塞 $30 \%$ 領域胆管のみの選択 的胆汁ドレナージ（SBD）施行のI群と，さらに30\% 領域を閉塞(以下 S-T) し, その後 1 週目に $30 \% \mathrm{SBD}$ 施行のII群に分けた。 TBOは 1 週間後に $30 \% \mathrm{SBD}$ 施 行しIII群とした。 SHは 1 週間後に全肝胆汁ドレナー シ $(100 \% \mathrm{BD})$ 施行しIV群とした。胆汁ドレナージは 実験 I と同様の操作で行い, 補液ならびにのちの胆汁 酸注入用のルートとすべく大腿静脈に polyethylene tube (3Fr.アトム)を抵入し, $0.9 \%$ 生理食塩水を 0.02 $\mathrm{ml} / \mathrm{min}$ の速度で注入した。

\section{1. 血液生化学および組織学的検討}

胆汁ドレナージ直前の 4 群のラット各 5 匹は脱血犠 死させ, 採肝した。血液は生化学検査に供し, 摘出肝 は10\%ホルマリンで固定後, Hematoxyline-Eosin 染 色施行した。な扔，3回の開腹を要す S-T では70\%領 域拡張胆管の限局性感染を示すものがあったため，以 後の胆汁分泌の検討に際しては, 特に開腹時所見に注 意し, 感染群は除外した。

2. 胆汁外㾇時の胆汁中総胆汁酸, 総ビリルビン排泄 測定

胆汁外瘦状態としたラットを Bollman cage に拘束 固定下 15 分間隔で 2 時間遮光下に胆汁採取し, 実験 I と同様, 胆汁流量測定後, 各分画の総胆汁酸濃度, 総 ビリルビン濃度を測定した。

3. 胆汁酸刺激下での胆汁分泌括よび総ビリルビン 排泄量測定

胆汁外瘻開始後 24 時間の胆汁洗い出しで出来るだけ 内因性胆汁酸を涸渴させたのち, 大腿静脈より sodium taurocholate（以下 Na-TCA, Sigma）を自動 注入ポンプ (501型, アトム)を用いて経時的に濃度を あげながら持続注入した。胆汁は20分ごとに120分まで 連続分画採取し, 各分画の胆汁流量, 総胆汁酸排泄量, 総ビリルビン排泄量を測定した. Na-TCA は40分ごと 
表 1 実験 I の血液生化学

\begin{tabular}{ccccccc} 
& $\begin{array}{c}\text { T-Bil } \\
(\mathrm{mg} / \mathrm{dl})\end{array}$ & $\begin{array}{c}\text { GOT } \\
(U)\end{array}$ & $\begin{array}{c}\text { GPT } \\
(U)\end{array}$ & $\begin{array}{c}\text { ALP } \\
(U)\end{array}$ & \multicolumn{2}{c}{ Bile Acid (nmol/mi) } \\
\hline $70 \%$ SBO & 0.3 & $461 \pm 82$ & $249 \pm 42$ & $38 \pm 7$ & $42 \pm 11$ & $169 \pm 49$ \\
$70 \%$ CCF & 0.3 & $189 \pm 52^{* *}$ & $29 \pm 9^{* *}$ & $33 \pm 11$ & $134 \pm 50^{* *}$ & $319 \pm 50^{* *}$ \\
Control & 0.3 & $200 \pm 56^{*}$ & $32 \pm 4.4^{* *}$ & $26 \pm 7^{*}$ & $24 \pm 9^{*}$ & $133 \pm 57$ \\
\hline
\end{tabular}

Mean \pm SD

$* p<0.05, * p<0.01$ vs SBO

に 3 段階まで上昇させ，最大負荷量を $75 \mu \mathrm{mole} / 100$ $\mathrm{gBW} / \mathrm{hr}$ に設定した。

\section{4. 統計学的解析}

測定値の有意差検定は Student $\mathrm{t}$ test を用い，危険 率 $5 \%$ 以下を有意差ありとした。

\section{結果}

実験 I.

1. 血液生化学的検討および組織学的検討

$70 \% \mathrm{SBO}, 70 \% \mathrm{CCF}$, control の SHいずれも総ビリ ルビン值は平均 $0.3 \mathrm{mg} / \mathrm{dl}$ で差がなかった. GOT, GPT は70\%SBO で他の 2 群に比べ有意に高かった が, 70\%CCFはSH と差がなかった。総胆汁酸濃度は $70 \% \mathrm{CCF}$ で末血わ門脈血ともに他の 2 群より有意に 高かった(表 1). 肝の組織像は光顕的には 3 者間で明 らかな差を認めなかった。

2. $30 \%$ 胆汁ドレナージ時の胆汁分泌拈よび総ビり ルビン排泄

総胆汁酸排泄量と胆汁流量との関係を linear regression で求め, その直線 $\mathrm{y}=\mathrm{ax}+\mathrm{b}$ に扮ける勾配 a およびy 切片 bを求めた（図 3). $70 \% \mathrm{SBO}$ での胆汁 酸依存性胆汁分泌 $(\mathrm{a}=29.9 \pm 6.19 \mu \mathrm{l} / \mu \mathrm{mol}, 95 \%$ 信頼 限界)はSH ( $\mathrm{a}=24.9 \pm 7.41)$ と同等であった。一方, $70 \% \mathrm{CCF}(\mathrm{a}=12.4 \pm 4.26)$ は70\%SBO, SH の両者に 比べ有意に低值であった。 b 值には明らかな差を認め なかった. 総ビリルビン排泄総量は70\%CCFで他の 2 群に比し有意に増加していた(図 4)，胆汁流量とビリ ルビン排泄量との間にも直線関係がえられたが，その 勾配 a は70\%CCF で0.045 00.010，70\%SBOで $0.0025 \pm 0.0006$ と， $70 \% \mathrm{CCF}$ が有意の高值を示した (図 5 ).

\section{実験 II.}

1. 血液生化学括よび組織学的検討

胆汁ドレナージ直前の血液生化学諸指標を表 2 に示 した.いずれの指標に関しても SH と SBOには明ら
表 2 実験IIの血液生化学

\begin{tabular}{|c|c|c|c|c|c|}
\hline & $\begin{array}{l}T-B I L \\
(n g / d I)\end{array}$ & $\begin{array}{r}\text { Bile Acid } \\
(n \in 01 / n \mid)\end{array}$ & $\begin{array}{c}\text { GOT } \\
(U)\end{array}$ & $\begin{array}{c}\text { GPT } \\
(U)\end{array}$ & $\begin{array}{c}A \perp P \\
(K A U)\end{array}$ \\
\hline SBO & $\begin{array}{l}0.27 \\
\pm 0.08 \\
\end{array}$ & $\begin{array}{l}12.7 \\
\pm 10.0\end{array}$ & $\begin{array}{l}232 \\
\pm 81\end{array}$ & $\begin{array}{l}56 \\
\pm 28\end{array}$ & $\begin{array}{l}22.5 \\
\pm 10.3\end{array}$ \\
\hline$S-T$ & $\begin{array}{l}5.25 \\
\pm 6.79\end{array}$ & $\begin{array}{l}270 \\
\pm 184\end{array}$ & $\begin{array}{l}844 * * \\
\pm 295\end{array}$ & $\begin{array}{r}184 \text { ** } \\
+ \\
\pm 52\end{array}$ & $\begin{array}{l}46.7 . \\
\pm 11.4\end{array}$ \\
\hline TBO & $\begin{array}{l}2.90 \\
\pm 1.37\end{array}$ & $\begin{array}{l}96 \\
\pm 73.6 \\
\end{array}$ & $\begin{array}{l}467 * * \\
\pm 108\end{array}$ & $\begin{array}{r}111 \\
\pm 39 \\
\end{array}$ & $\begin{array}{l}39.1 \\
\pm 8.5\end{array}$ \\
\hline $\mathrm{SH}$ & $\begin{array}{l}0.32 \\
\pm 0.04 \\
\end{array}$ & $\begin{array}{l}9.2 \\
\pm 8.3\end{array}$ & $\begin{array}{l}192 \\
\pm 103\end{array}$ & $\begin{array}{l}50 \\
\pm 9 \\
\end{array}$ & $\begin{array}{r}26.3 \\
\pm 3.4\end{array}$ \\
\hline
\end{tabular}

図 $330 \%$ 選択的胆管ドレナージ後の総胆汁酸排泄と 胆汁流量との関係

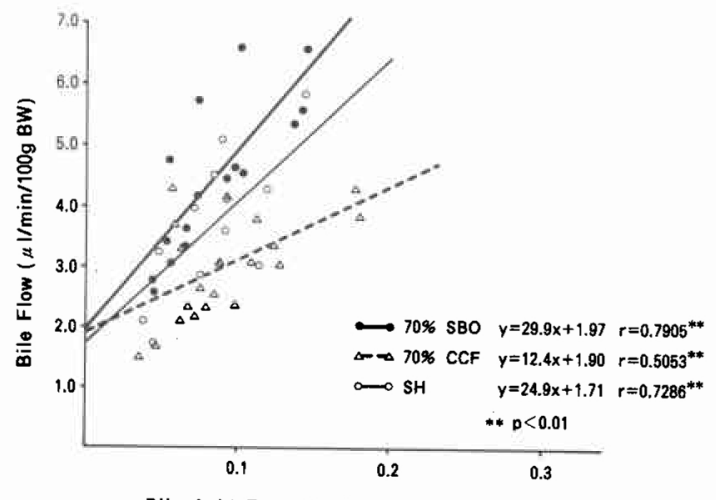

Bile Acid Excretion ( $\mu \mathrm{mol} / \mathrm{min} / 100 \mathrm{~g} \mathrm{BW}$ )

かな差がみられなかった。一方， S-T, TBO ともに各 指標は SBO, SH に比べ高値を示した, GOT, GPT に 関し, S-T は TBO 上り有意に高值を示した. 光顕肝組 織像を右葉と中葉でみた(図 6 ). SH と SBO とで光顕 的には特に差を認めず特別の所見もなかった。一方, 
S-T, TBO はともに顕著な変化をみせた. TBO は偽胆 管の著明な増生をみたが，線維化は未だ軽度に留まっ ていた．S-Tは門脈域の著明な線維化，偽胆管増生， 細胞浸潤が強く, 巣状壊死も散見した。閉塞期間の長 い中葉で閉塞期間の短い右葉より高度の変化がみられ

図 $430 \%$ 選択的胆管ドレナージ後の胆汁中総ビりル ビン排泄総量

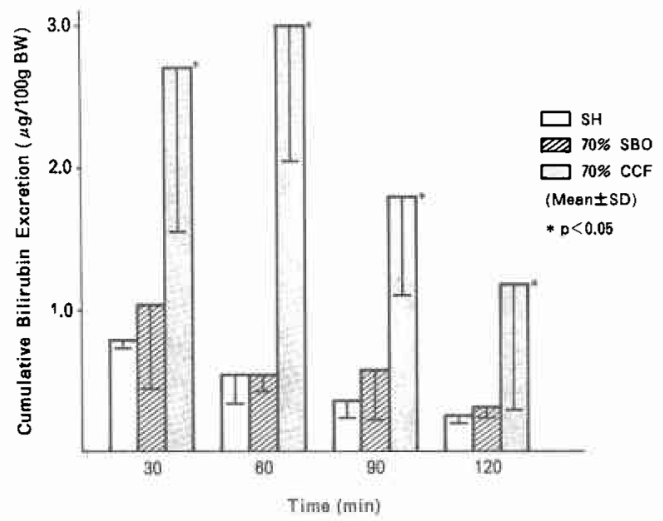

た。

2. 胆管閉塞部分的解除後の胆汁分泌と胆汁中総ビ リルビン排泄

選択的胆管ドレナージ後の胆汁酸の胆汁中排泄をみ た（図 7)，胆汁ドレナージ後120分でII 群 (S-T), III

図 $530 \%$ 選択的胆管ドレナージ後の胆汁流量と総ビ リルビン排泄量との関係

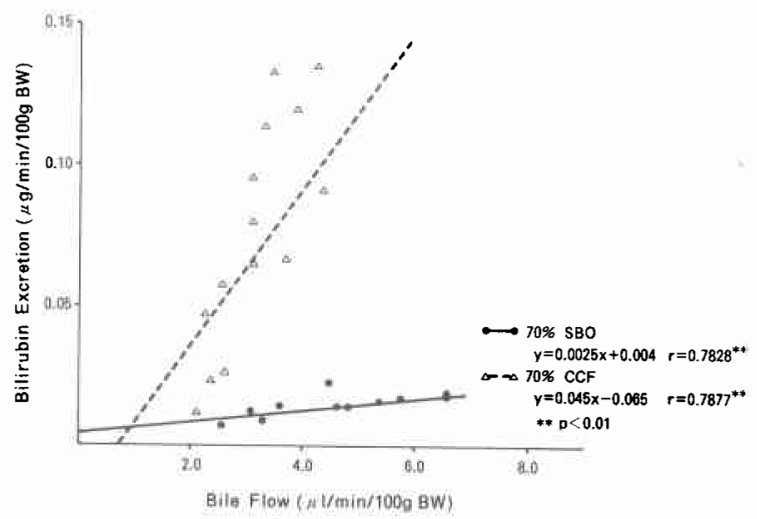

図 6 実験II の肝組織・光顕像.I 群とIV群に差はなく, III群はIII群 R（右葉）之同 等の障害度を示した. II群 $\mathrm{M}$ (中葉) で最も強い線維化を認めた.

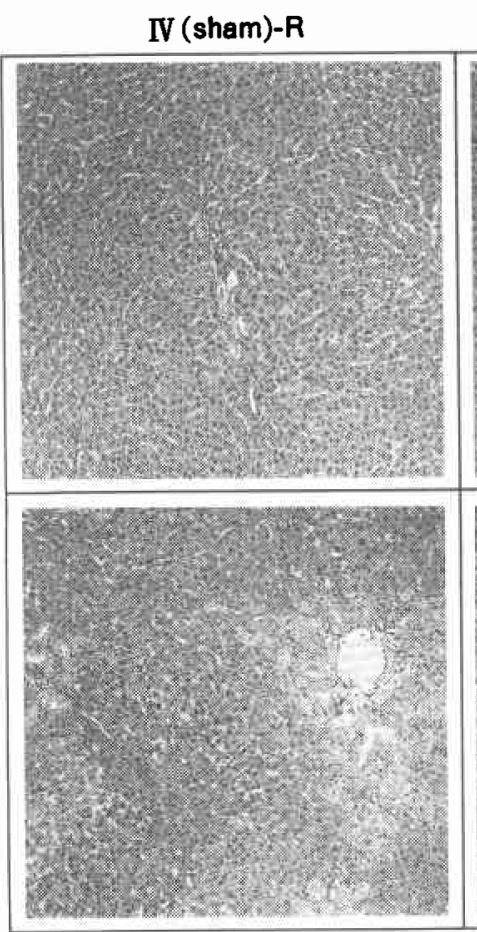

III (TBO)-R
I (SBO)-R

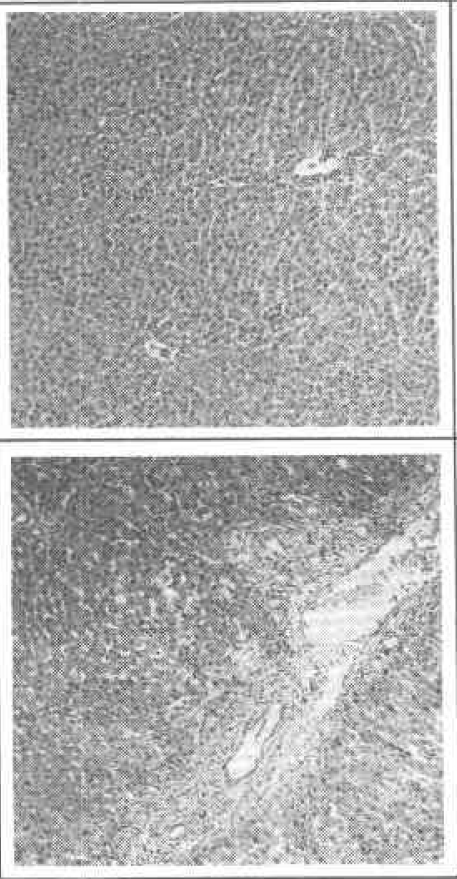

II (S-T)-R
I (SBO)-M

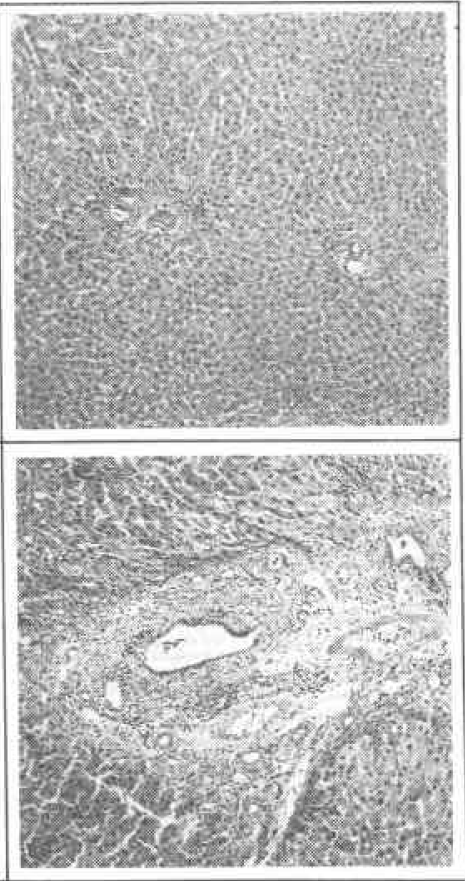

II (S-T)-M 
図 $730 \%$ 選択的閉塞解除後の胆汁中総胆汁酸排泄量

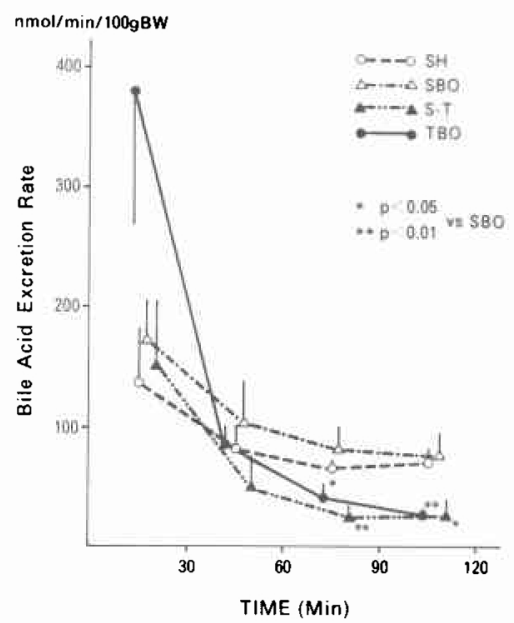

図 $830 \%$ 選択的閉塞解除後の総胆汁酸排泄量之胆汁 流量との関係

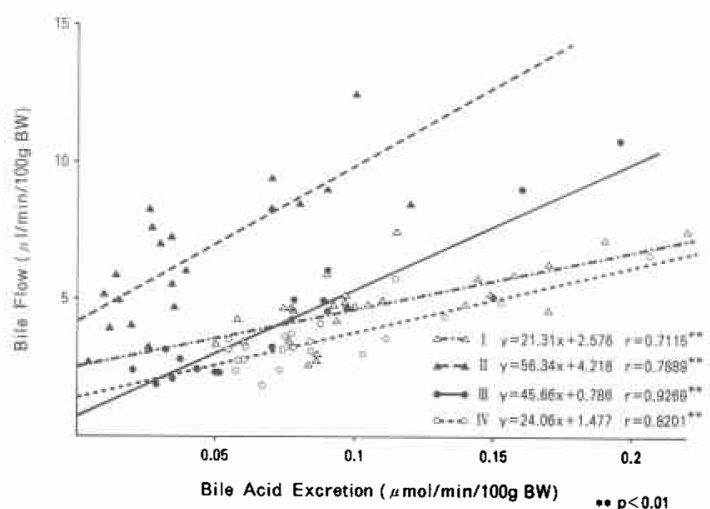

群 (TBO) の胆汁酸排泄量は I 群 (SBO), IV群 (SH) に比べ有意に低値であった。胆汁中総胆汁酸排泄量と の関係を linear regressionでもとめた(図 8). II 群で は $\mathrm{a}=56.34 \pm 10.3 \mu \mathrm{l} / \mu \mathrm{mol}$, III 群では $\mathrm{a}=45.66 \pm$ $4.62 \mu \mathrm{l} / \mu \mathrm{mol}$ と, I 群の a 値21.31士4.21, IV群の a 值 $24.06 \pm 3.82$ k対し有意の増加を認めた. II 群の b 倌 はIII, IV群のb值に比べ有意に増加していた。総ビリ ルビン排泄総量にはII，III群とI，IV群との間に顕著 な差を認めた(図 9)。II，III群では経時的減少をみた が，II群とIII群との相互間には差がなかった，胆汁酸 依存性のビリルビン排泄についてみても, III群（ $\mathrm{a}=$ $36.88 \pm 22.7 \mu \mathrm{g} / \mu \mathrm{mol})$ とII 群 $(\mathrm{a}=23.04 \pm 18.1)$ とで 差を認めなかった（図10）。

3. 胆汁酸持続負荷時の胆汁分泌と総ビリルビン排
図 $930 \%$ 選択的閉塞解除後の胆汁中総ビリルビン排 泄総量

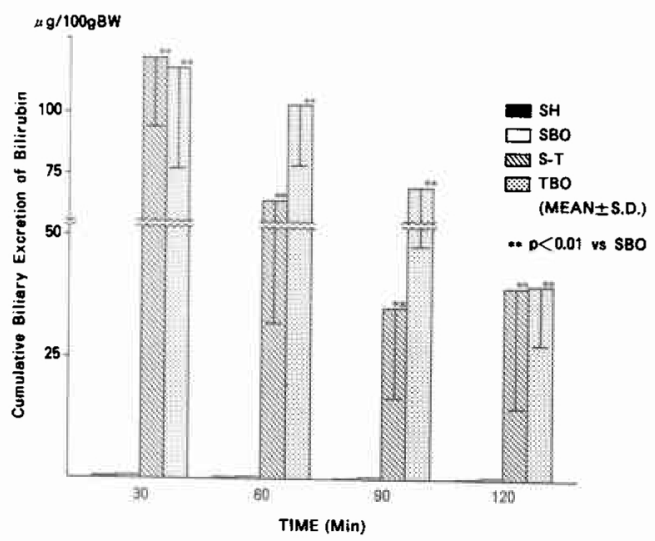

図10 30\%選択的閉塞解除後の総胆汁酸排泄と総ビリ ルビン排泄との相関

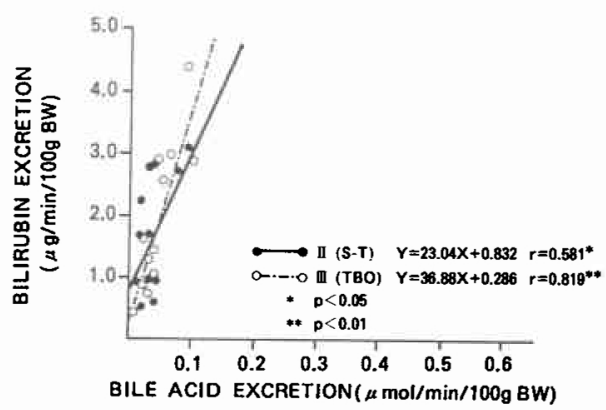

図11タウロコール酸持続注入時の総胆汁酸排泄と胆 汁流量との関係

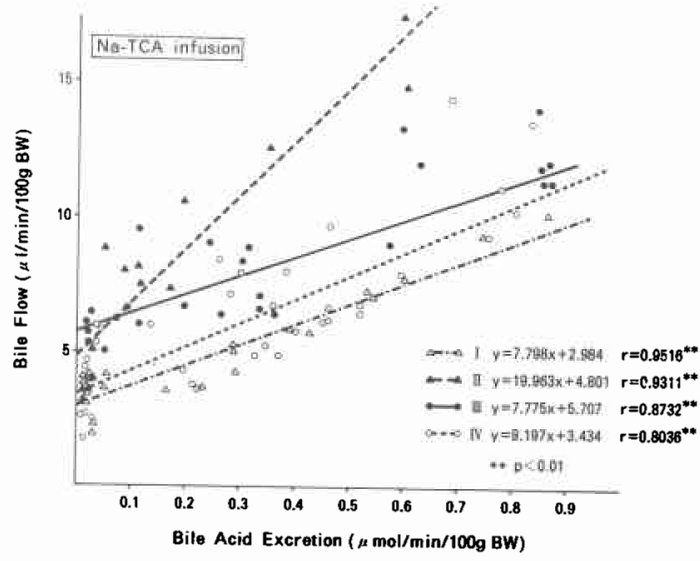

模

Na-TCA 持続負荷時の胆汁中総胆汁酸排泄量之胆 
図12 タウロコール酸持続注入時の胆汁流量と総ビリ ルビン排泄との関係

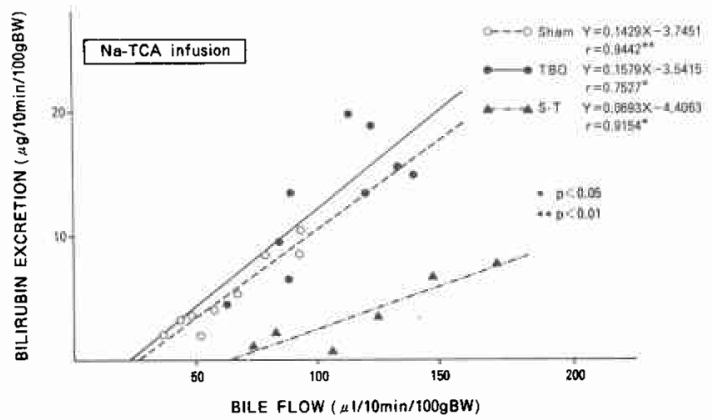

汁流量との関係を linear reression で求めた（図11）. 胆汁酸依存性の胆斗分泌量は II 群（ $\mathrm{a}=19.96 \pm 2.25$ $\mu \mathrm{l} / \mu \mathrm{mol}$ ) で他の 3 群に比べ（ I 群: 7.79土0.56, III 群 : $7.77 \pm 0.90$, IV 群 : $9.19 \pm 1.20 \mu \mathrm{l} / \mu \mathrm{mol}$ )有意の増 加を認めた。 Na-TCA 持続負荷により胆汁流量の増加 に伴らビリルビン排泄量の直線的な増加をII, III, IV 群で認めた（図12）. II群の勾配a（胆汁 $1 \mu 1$ の排泄に 対応するビリルビン排泄量)は $0.069 \pm 0.01 \mu \mathrm{g} / \mu \mathrm{I}$ でIII 群 $(0.158 \pm 0.05)$, IV群 $(0.143 \pm 0.02)$ に比べ有意に 低値であった。

\section{考察}

閉塞性黄疸解除後の胆汁分泌に関するラットを用い た実験的検討は数多くみられる ${ }^{9) \sim 12)}$ ものの，そのいず れも年純に肝外総胆管を膵上縁可及的下方で結紮切断 する下部胆管閉塞を想定させるモデルであり，した がってその結果を肝門部胆管癌のような肝門部で胆管 が分断されている病態に直ちにあてはめるわけにはい かないことは自明であろう、われわれはラット肝が分 葉しており，各葉の胆管子独立分離しつつ一つの集合 管である総胆管を形成していることに着目し，基本的 に70\%領域に相当する肝葉の胆管を選択的に遮断する 選択的胆管閉塞モデルを作成し，肝門部胆管閉塞を想 定した各肝葉の胆道閉塞期間が異なる胆管閉塞病態で の胆汁分泌の検討を試みた。

胆汁分泌の測定に際しては臨床での片側胆管ドレ ナージを念頭におき $30 \%$ 領域胆管のみの胆汁ドレナー ジを施行した，日常臨床では通常一側の胆管のみのド レーナジが汎用され，小わゆる減黄不良例を除くと比 較的良好な減黄効果が得られている。複数胆管枝のド レナージ13)は繁雑のみならずカテーテル・トラブルな どの管理上の問題を無視できず，また胆管炎を併発し た場合は減黄期間の延長にる熬がる. 術後合併症・死
亡率の頻度は術前 PTCD の有無で統計学的に差がな かったとする欧米の報告3 ${ }^{3)}$ もみられ, 術前 PTCDの 意義に関し再考を迫られている現状がある.PTCDに よる外瘻よりの早期離脱，早期手術という方針の実現 にはできるだけ短期間の片側胆管ドレナージが最も望 ましいと思われ，したがってその選択的胆汁分泌機構 の解明は極めて重要であると考党たわけである.

减黄効果, すなわち血清ビリルビン值の低下には胆 汁中へのビリルビン排泄量が最も関連深く重要と考兄 られている12). 閉塞性黄疸解除後では肝細胞より毛細 胆管へのビリルビン排泄は，1）胆汁酸依存性の排泄， 2) 胆汁酸非依存性 $\left(\mathrm{Na}^{+}-\mathrm{K}^{+}\right.$-ATPase に基つくく $\mathrm{Na}$ ポ ンプによる)の排泄，3）毛細胆管周囲性微細線維網に よる排泄 ${ }^{14)} 3$ 種のメカニズムが想定されるが，なか でも胆汁酸依存性のビリルビン排泄が主役をなすと考 宇れている。

そこでまず，胆汁中へのビリルビン排泄に影響する 病態を明らかにすべく，選択的胆管閉塞モデルおよび 部分的胆汁血症モデルを作成した，諸家の報告6)同様， 48時間の短期 $70 \%$ 選択的胆管閉塞は非閉塞葉の機能的 代償により，黄疸を伴わず，非閉塞・対照と同等の胆 汁排泄能を示した。ビリルビン排泄に関しても対照と 差がなかった。一万，胆汁の流出路を静脈としたため 胆管閉塞に基つく胆汁うっ滞や胆汁分泌阻害を伴わな い部分的胆汁血症下では，30\%葉の胆汁分泌の機能昂 進は認められなかった。しかし注目すべきことに，黄 疸がなく胆道閉塞病態がないにも関わらずビリルビン 排泄の著増が認められた。これは，肝腸循環をしない 胆汁分画の直接的再循環による血中胆汁酸ならびに毛 細胆管を通過する胆汁酸の高濃度化機転 ${ }^{15) 16)}$, 胆汁成 分の体内蓄積機転がビリルビンの胆汁排泄に大いに関 与していることを示すものといえよう．選択的胆管閉 塞はその長期病態でも胆汁中へのビリルビンの排泄に 変動がないことより,ビリルビン排泄量の多夏の基本 的決定因子がビリルビンの体内蓄積量であることは論 を待たないと思われる、したがって, 胆汁成分の体内 蓄積量, 胆汁酸生成量に差があると想像される種々の 完全胆道閉塞状態では, 胆汁外㾞時のビリルビン排泄 動態にも自ずから違いが生じることがうかがえた

胆道閉塞解除直後には大量の蓄積された胆汁酸が胆 汁中に排泄されるが, 胆道閉塞による胆汁酸合成低下 とドレナージによる急速な胆汁酸プールの放出が相 まって, 胆汁酸排泄量は急速に低下することが知られ ている12)17)18). 今回の検討で, $30 \%$ 選択的胆管ドレナー 
ジでも同様な傾向での胆汁酸排泄をみ, 黄疸のないも のに比べ黄㾞群での排泄量の低下が著しかった。しか し, 胆汁酸 $1 \mu$ mole の排泄に相当する胆汁量は閉塞性 黄㾞群で有意に増加していた。さらに，24時間の胆汁 外瘦で内因性胆汁酸プールを可及的に涸渴させたのち 胆汁酸を持続的に負荷すると, $70 \%$ 葉の閉塞が長期化 し 3 週間に及んだものでは著しい利胆効率が得られ た.このような閉塞性黄疸群にみる閉塞解除後の利胆 効果は, 持続せる $70 \%$ 閉塞葉の存在ならびにその障害 度と無関係ではないと思われる。

胆汁中総胆汁排泄之同様, 胆道閉塞解除直後には $70 \%$ 葉閉塞 1 週間群, 3 週間群ともに大量の蓄積され たビリルビンの排泄がみられた。胆道閉塞解除時には 胆汁中総胆汁酸排泄量と総ビリルビン排泄量とがよく

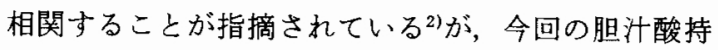
続負荷時の検討では両者間に著しい解離のみられるも のがありむしろ胆汁流量とビリルビンとの間により よい相関をみた。興味あることに, 利胆効果の最もよ かった $70 \%$ 莱閉塞 3 週間群で, 単位胆汁当たりのビリ ルビン排泄効率が極めて悪い結果を得た。70\%葉閉塞 1 週間群は対照と同等のビリルビン排泄能を示したこ とより,これはすなわち, 部分的胆道減圧に際しては, 胆道減圧がなされていない閉塞葉の閉塞期間の差でビ リルビン排泄能，いいかえれば減黄効果が大きく変わ ることを示するのとい党る。

胆道閉塞解除直後はしばしば無色透明のいわゆる白 色胆汁を認めることが多い. しかし, 減黄後 $1 \sim 2$ 時 間で白色から黄色に変わることもしばしば経験すると ころである ${ }^{19)}$. 減黄効果不良ないしは黄疸の遷延を認 める症例では胆汁排泄の減少ないしはこのような希薄 胆汁の存在が指摘されており ${ }^{20121)}$, 主として胆道感染 の関与が示唆されている. 胆管閉塞の長期化で閉塞肝 葉は病理学的に種々の高度の変化を来すが, 経過中に ドレナージ胆管の胆管炎の合併 ${ }^{22}$ 多否めない. 今回の 検討で, このような従来よりの観点を裏打ちするごと く,ドレナージしていない胆管閉塞葉での病態がドレ ナージ側の胆汁分泌・ビリルビン排泄に影響するとい 5 ，希薄胆汁に関する重要な所見が得られた，原因々 して閉塞肝葉の肝線維化に伴うセクレチンの体内蓄積

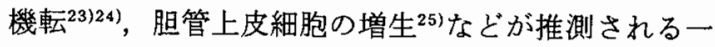
方, 胆汁酸依存性胆汁分泌は有効に働いているのに何 らかの原因で色素排泄機構の及が障害されているとも 考爷られる.このビリルビン排泄障害の本態ならびに 障害部位に関しては明らかでなく，今後の検討を要す
る所である，臨床的に胆汁外瘻が長期化し減黄効果が 不良である場合, 内因性胆汁酸プールが涸渴するにも 関わらず肝細胞での胆汁酸合成障害が存在することが 多く, 胆汁酸の利胆作用, ビリルビン排泄促進作用を 期待して胆汁酸の補充投与の意義が強調されてい る ${ }^{12)}$. しかし，一側胆管ドレナージを施行している肝門 胆管閉塞では症例により胆汁酸投与はむしろ希薄胆汁 を助長し, 减黄効果に役立たないことが示唆された。 したがってこのような症例では, 胆汁分泌能・ビリル ビン排泄状態をよく判断し，いたずらに長期減黄処置 に委权ることで手術的治療の時期を誤ることのないよ ら，主病巣および非ドレナージ胆管閉塞葉を含めた可 及的速やかな手術的除去乃至は閉塞胆管の内瘦化を図 ることが肝要と考えられた。

\section{結論}

ラットに肝門部胆管閉塞に擬したモデルを作成し $30 \%$ 領域胆管の部分的胆道減圧術後の胆汁分泌動態, ビリルビン排泄につき検討し以下の結果を得た。

1） $70 \%$ 選択的胆管閉塞は, 黄疸を認めず，その閉塞 期間の長短に関わらず対照と同等の胆汁分泌能, ビリ ルビン排泄能を示した。

2）選択的胆汁血症は, 胆汁分泌を六進させずビリル ビン排泄の著明な増加をみせた。

3） $70 \%$ 領域胆管と $30 \%$ 領域胆管の同時選択的閉塞 1 週間群では, 胆道减圧 24 時間後に対照と同等の胆汁 分泌能ビリルビン排泄能が認められた。

4） $70 \%$ 領域胆管閉塞 2 週間後に $30 \%$ 領域胆管の閉 塞がさらに 1 週間続く異時選択的胆道閉塞群では, 胆 道減厈 24 時間後に, 胆汁分泌能の亢進, ビリルビン排 泄能の著しい低下が認められた。

な报, 本研究の一部は昭和62年度兵庫医科大学研究助成 費によった。

1）小沢国雄：閉塞性黄疸に対する経皮的胆管ドレ ナージの胆汁組成之黄瘟俥減効果. 日外会誌 $80: 916-930,1979$

2）津田 寛, 古屋清一, 近藤芳夫沿か：胆道閉塞解除 後における胆汁酸排泄とビリルビン排泄汇関する 実験的研究. 肝臓 $26: 80-87,1985$

3) Hatfield ARW, Tobias R, Terblanche $J$ et al: Preoperative external biliary drainage in obstructive jaundice. A prospective controlled clinical trial. Lancet ii : 896-899, 1982

4) Norlander A, Kalin B, Sundblad R: Effect of percutaneous transhepatic biliary drainage upon liver function and postoperative mortal- 
ity. Surg Gynecol Obstet $155: 161-166,1982$

5) McPherson GAD, Benjamin IS, Hodgson $\mathrm{HJF}$ et al: Preoperative percutaneous transhepatic biliary drainage: The results of a controlled trial. Br J Surg $71: 371-375,1984$

6) Adler R D, Wannagat FJ, Ockner RK: Bile secretion in selective biliary obstruction. Adaptation of taurocholate transport maximum to increased secretory load in the rat. Gastroenterology $73: 129-136,1977$

7）真重文子, 柳沢悦子, 大菅俊明：血中胆汁酸の簡易 貒量定量法. 臨化学 $4: 312-318,1976$

8) Mallory H, Evelyn K: Determination of bilirubin with the photoelectric colorimeter. J Biol Chem 119:481-490, 1937

9) Kountouras J, Scheuer PJ, Billing BH : Effect of prolonged bile duct obstruction in the rat on hepatic transport of bilirubin. Clinical Sci 68 : $341-347,1985$

10) Accatino L, Contreras A, Fernandez $S$ et al: The effect of complete biliary obstruction on bile flow and bile acid excretion: Postcholestatic choleresis in the rat. J Lab Clin Med 93: 706-717, 1979

11) Cleland DP, Bartholomew TC, Billing BH : Hepatic transport of sulfated and non-sulfated bile acids in the rat following relief of bile duct obstruction. Hepatology $4: 477-485,1984$

12）津田 寛：胆道閉塞解除後に打ける胆汁酸補充投 与の意義に関する実験的および臨床的研究. 日外 会誌 $87: 759-773,1986$

13）神谷順一, 二村雄次, 早川直和ほか：緊急経皮経肝 胆道ドレナージ術. 腹部球急診療の進歩 $7: 153$ $-157,1987$

14) Elias E, Heruban $Z$, Wade JB et al : Phalloidin-induced cholestasis: A microfilament-mediated change in junctional com- plex permeability. Proc Natl Acad Sci $77: 2229$ $-2233,1980$

15) Hardison WGM, Hatoff DE, Miyai $K$ et al: Nature of bile acid maximum secretory rate in the rat. Am J Physiol 241 : G337-G343, 1981

16) Hardison WGM, Weiner RG, Hatoff $D E$ et al : Similarities and differences between models of extrahepatic biliary obstruction and complete biliary retention without obstruction in the rat. Hepatology $3: 383-390,1983$

17) 白川洋一, 玉熊正悦: 胆道閉塞解除後の胆汁分泌. 医のあゆみ $115: 912-919,1980$

18）白川洋一：胆道閉塞解除後の胆汁分泌機序と胆汁 酸排泄の臨床的意義に関する研究. 日外会誌 $82: 633-646,1981$

19）小林 衛, 嶋田 紘, 石黒直樹住：閉塞性黄疸に おける白色胆汁およびその正常化について，日臨 外医会誌 $39: 43-48,1978$

20）野口 孝, 武内徹郎, 水本龍二：肝外閉塞性黄㾞に 括ける色素排泄機構と肝溦細構造の変化につい て. 特に黄㾝遷延例の検討. 肝践 $21: 1730$ $-1731,1980$

21）永川宅和, 清水康一, 太田哲生ほか：PTCD 後の 胆汁分泌能の開復と減黄効果について. 胆と膵 $3: 1061-1065,1982$

22）田中信孝, 网本英三, 鈴木栄太郎：閉塞性黄㾝にお ける胆道感染重篤化に関する実験的研究. 腹部救 急診療の進歩 7:333-336, 1987

23) Balaband C, Noel M, Dangomon J : Influence of secretin on bile production in rat. J Pharmacol $8: 191-196,1977$

24）膳所富士男, 山口 建, 阿部 蒸 : 胆道, 脺疾患と 消化管ホルモン。臨成人病 7:1501-1508, 1977

25) Goldfarb S, Singer EJ, Popper H: Biliary ductules and bile secr etion. J Lab Clin Med $62: 608-615,1963$ 